
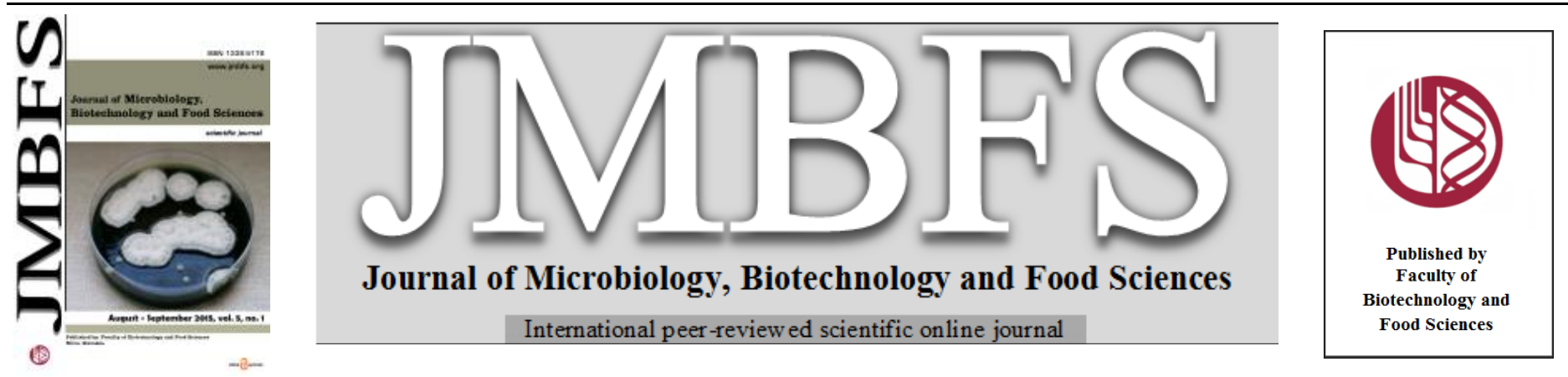

\title{
THE MICROBIOLOGICAL QUALITY OF ANEMOPHILOUS POLLEN WITH ALLERGENIC POTENTIAL AFTER COLLECTION AND STORAGE
}

\section{Tetiana Shevtsova ${ }^{* 1}$, Jana Petrová2 ${ }^{2}$ Ján Brindza ${ }^{3}$,Kateryna Garkava ${ }^{1}$, Rafal Kordiaka ${ }^{4}$, Miroslava Kačániová2}

Address(es): Mgr. Tetiana Shevtsova,

${ }^{1}$ National Aviation University, Institute of Ecological Safety, Department of Biotechnology, Kosmonavta Komarova ave., 1, 03680 Kyiv, Ukraine;

${ }^{2}$ Slovak University of Agriculture in Nitra, Faculty of Biotechnology and Food Sciences, Department of Microbiology, Tr. A. Hlinku 2, 94976 Nitra, Slovak Republic; ${ }^{3}$ Slovak University of Agriculture in Nitra, Institute of Biodiversity Conservation and Biosafety, Tr. A. Hlinku 2, 94976 Nitra, Slovak Republic;

${ }^{4}$ Faculty of Biology and Agriculture, University of Rzeszów, 2 Ćwiklińskiej St., 35-601 Rzeszów, Poland.

*Corresponding author: shevtsovat@ukr.net

doi: 10.15414/jmbfs.2015.5.1.81-87

\section{ARTICLE INFO}

Received 23. 5. 2015

Revised 17. 6. 2015

Accepted 25. 6. 2015

Published 1. 8. 2015

Regular article

open 2 Access

\begin{abstract}
The aim of this study is to determine and compare microbiological contamination of anemophilous pollens (Betula verrucosa Ehrh., Betula verrucosa Ehrh. 'Youngii', Pinus sylvestris L., Pinus nigra Arnold, Pinus mugo Turra, Pinus armandii Franch., Pinus wallichiana A.B. Jacks) after collection and after not long-term storage. Samples were picked by hands aseptically in the territory of the same environmental conditions in Slovakia. Colonies of mesophilic aerobic and anaerobic bacteria, lactobacilli, total coliforms, fungi and yeast were found on pollen samples by dilution plating method. It was found significant differences in content of lactobacilli for birch pollens and fungi and yeast on pine pollens, depending on the stages - collection and storage. The microbiological quality of Betula pollen is better than Pinus pollen after collection and storage. Species factor affects the microbiota of anemophilous pollen.
\end{abstract}

Keywords: Anemophilous pollen, pollen handling, storage, microorganisms, Betula, Pinus

\section{INTRODUCTION}

Storage - the last stage before using pollen. Before that pollen collect, dry, clean, pack, use or keep. From the hygienic point of view, microbiological safety is the main quality criterion in bee pollen (Feás et al., 2012). Pollen requires careful and considerate handling, just like any other plant product.

Already before the collection anemophilous pollen contains microorganisms associations (Śpiewak et al., 1996; Masclaux et al., 2011). It is natural, since this plant component is rich in nutrients (Medina et al., 2004; Brovarskij et al., 2010), and microorganisms are supplied with mechanisms for obtaining these substances (Madmony et al., 2005). For example, chytrids are among the few microorganisms able to overcome the barrier created by the exine and to grow on pollen. They might, thus, play an important role in damaging the pollen wall in order to permit other organisms, such as bacteria, to gain access to the cytoplasmic content of pollen (Masclaux et al., 2011). Alternatively microorganisms may be airborne contaminants that alight on the pollen during collection and processing (Madmony et al., 2005; Brindza et al., 2010; Shevtsova et al., 2013; Kačániová et al., 2014; Shevtsova et al., 2014).

The process of collecting of anemophilous pollen is carried out manually. Collect this type of pollen, for example, for the production of allergenic drugs. It is possible to collect plant material in natural conditions before flowering, or to create the conditions of maturation in special rooms at the manufacture. Collecting, drying, cleaning will bring some pollen contamination by microorganisms. The main condition for the further application of the pollen is its microbiological quality, i.e. the content of certain groups of microorganisms within a certain range. Many scientists are working and already have results on the development of recommendations for bee pollen handling (Bogdanov, 2004; Campos et al., 2008; Brovarskij et al., 2010; Hani et al., 2012; Nôžková et al., 2014). In connection with the fact of the microbial contamination of allergenic extracts (Mittag et al., 2013) in the treatment of hay fever, it is important to have a view of microbiota of pollen with allergenic potential. Therefore, the aim of this study is to examine the microbiological quality of pollen with allergenic potential after collection and storage. Two genus of plants were selected: Betula and Pinus. They are the representatives of the strong and weak pollen allergens and are common in European countries (D'Amato et al., 2007; Gastaminza et al., 2009).

\section{MATERIALS AND METHODS}

\section{Sampling and storage}

The plant material was collected in April-May 2015 in the Botanical garden (BG) of the Slovak Agricultural University in Nitra. Topographic data of the BG are: altitude $144 \mathrm{~m}$, east longitude $18^{\circ} 06^{\prime}$ and north latitude $48^{\circ} 19^{\prime}$. Pollen has been collected in the same area in order to eliminate the various effect of factor "habitat".

Betula pollen has been collected from species Betula verrucosa Ehrh. (BV1) (syn. B. pendula Roth.) and its cultivar - Betula verrucosa Ehrh. 'Youngii' (BV2) Pinus pollen has been collected from the five species: 1PS, 2PS - Pinus sylvestris L., 3PN - Pinus nigra Arnold, 4PM - Pinus mugo Turra, 5PA - Pinus armandii Franch., 6PW - Pinus wallichiana A.B. Jacks. All the trees were without visible damage. The general view of the studied trees and their male generative organs are shown in Figure 1.

Pollen samples were collected by adhering sterile conditions. Pollen was dried at room temperature overnight and collected the next day, keeping sterile conditions. Samples were placed in a cooler and conserved until analysis at $+4^{\circ} \mathrm{C}$. Since some Pinus species flowered with a difference of one month, the microbiological analysis of pollen samples was carried out as to collect the material. 


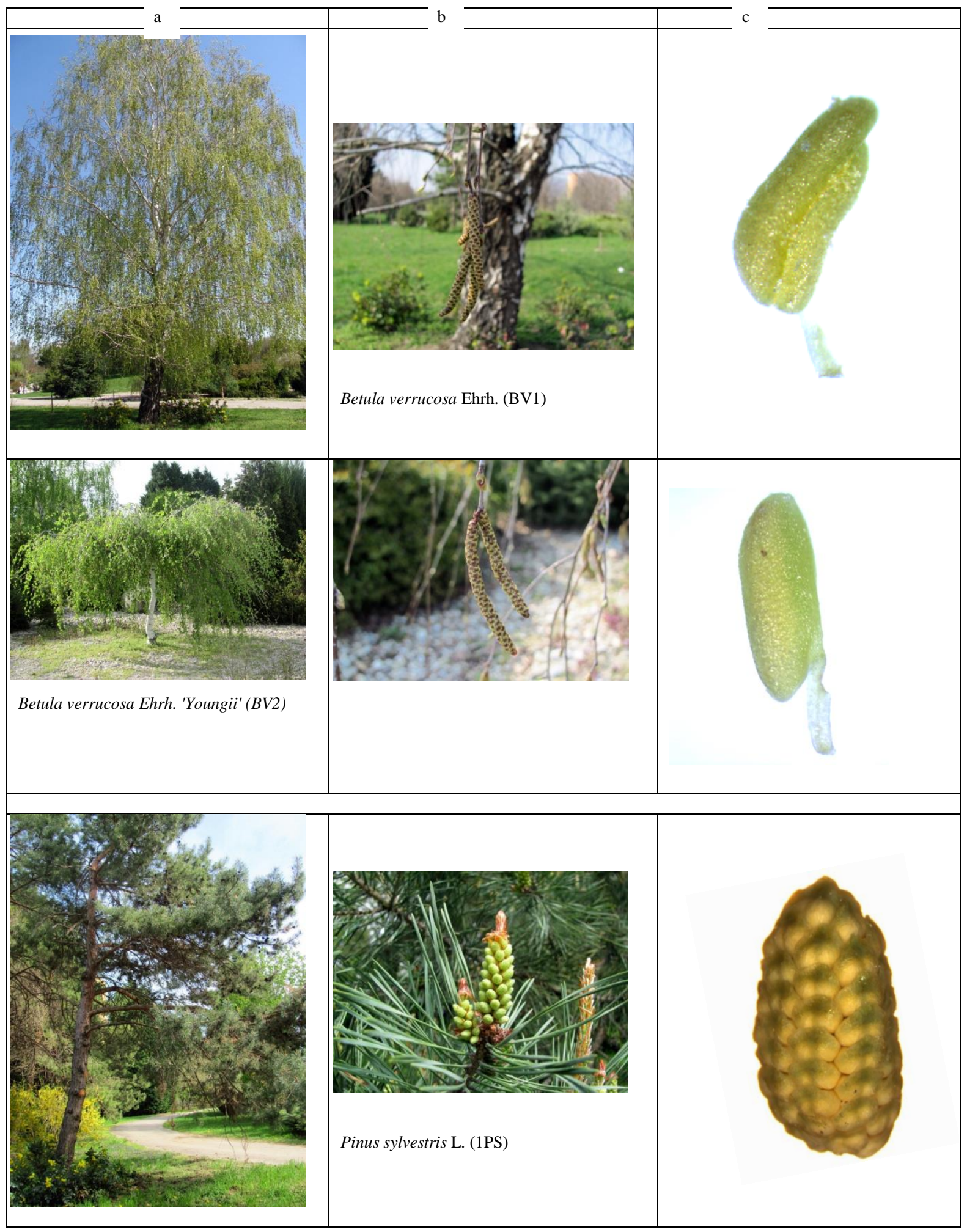




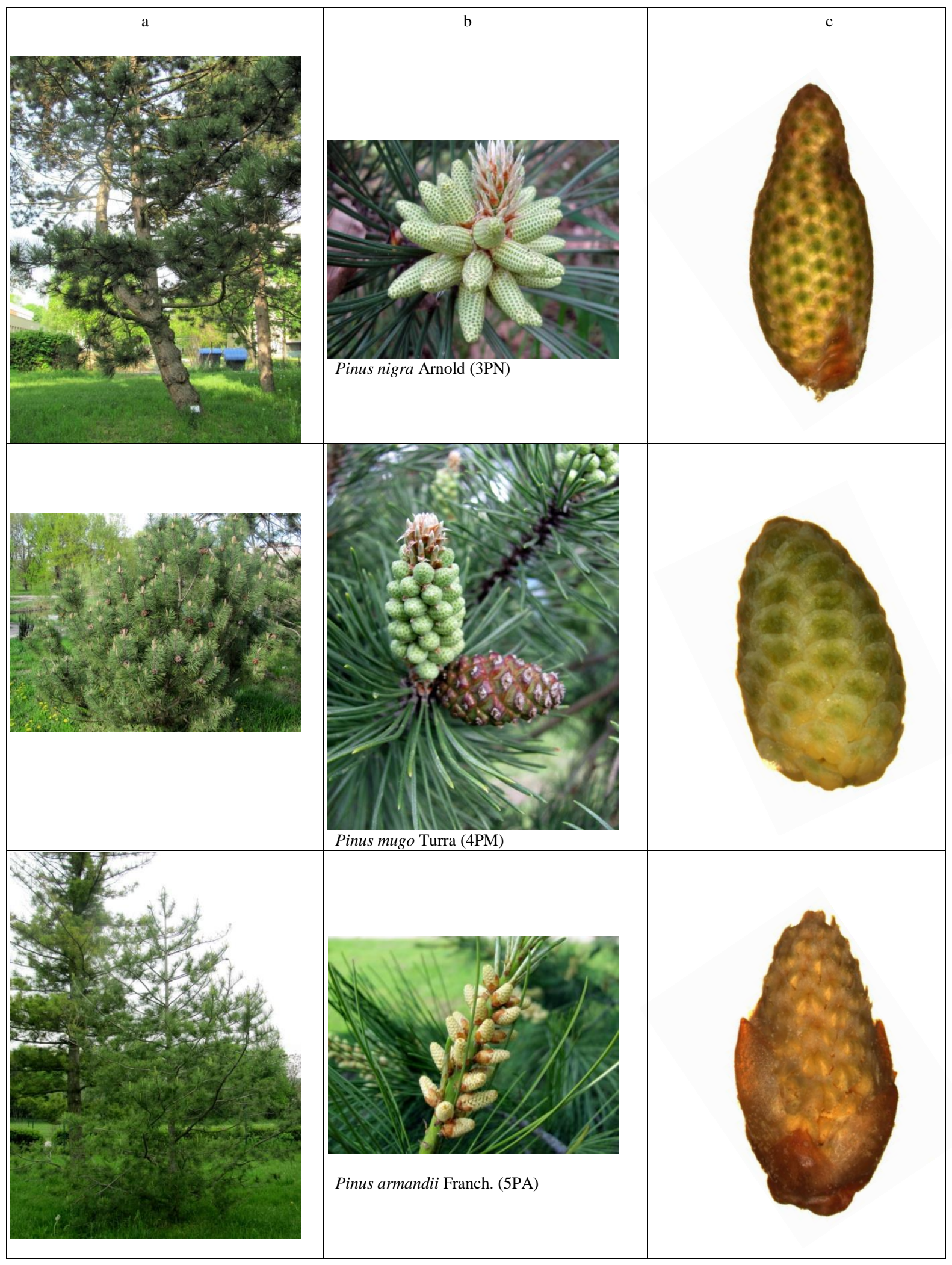




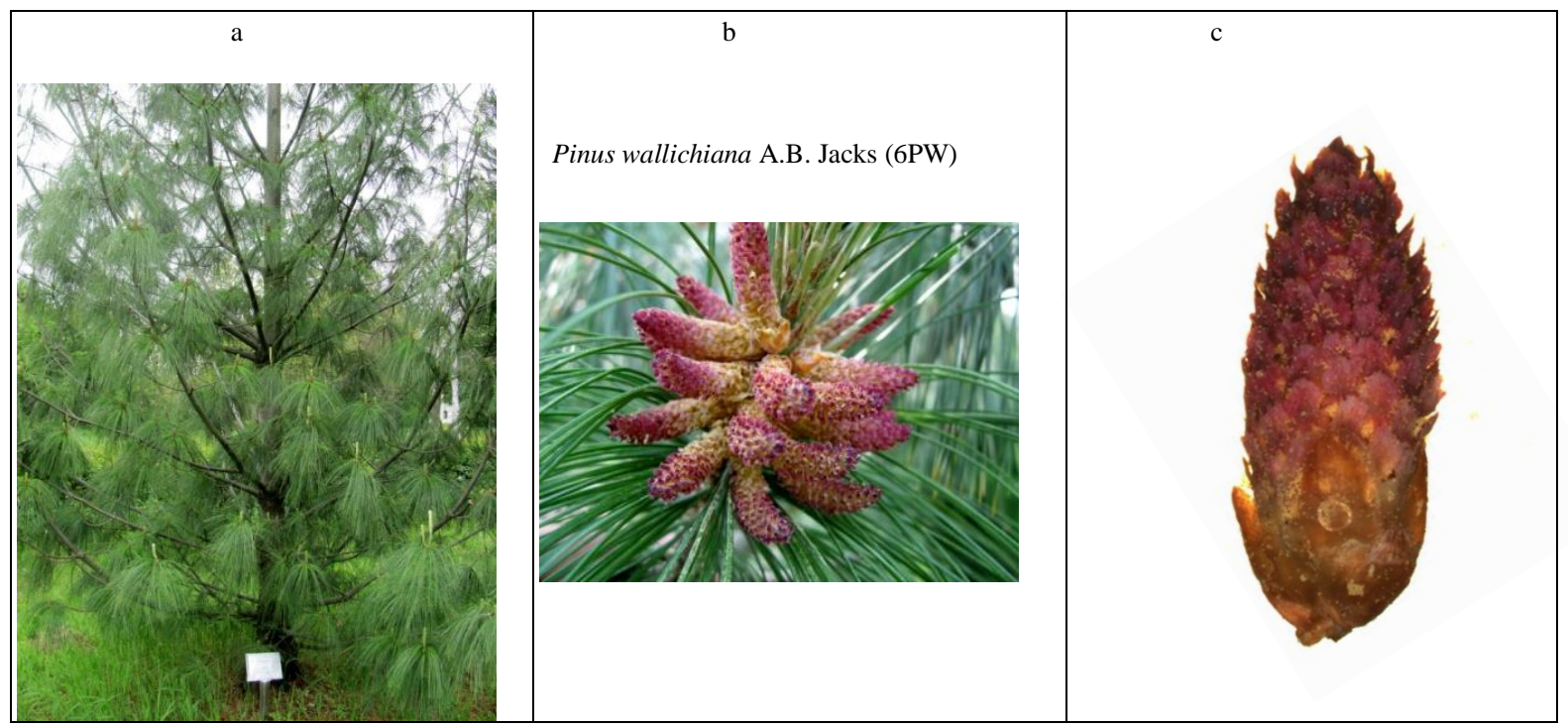

Figure 1 General view of studied species Betula, Pinus and their male organs: $a$ - tree; $b$ - male generative organ; $c$ - anther (x 10) (Photos $a, b$ by digital camera Canon Power Shot SX120, c - by stereo microscope Zeiss Discovery V12, T. Shevtova \& A. Oravec)

\section{Microbial analysis}

Several groups of microorganisms were selected for the analysis on the basis of literature data and properties of microorganisms that can affect the quality of plant material. They are mesophilic aerobic bacteria, mesophilic anaerobic bacteria, lactobacilli, representatives of Enterococcus genus, total coliforms, fungi and yeast. Thus, microscopic fungi can produce toxic metabolites during storage, coliforms are indicators of microbiological purity, mesophilic anaerobic bacteria, from the viewpoint of food microbiology, are undesirable and grow well in aggregation with aerobic spore-forming bacteria (Medina et al., 2004; Nôžková et al., 2014). The presence of lactic acid bacteria is a favorable indicator of quality.

The concentration of microorganisms in the pollen samples was determined by dilution plating method. One gram of each sample was suspended in $99 \mathrm{ml}$ of sterile saline solution. After vigorous shaking during 30 minutes at room temperature, 10 -fold serial dilutions were made up to $10^{-3}$. The $1000 \mu \mathrm{l}$ aliquots of each dilution were spread on duplicate sets of media appropriate for determination of all group bacteria and $100 \mu \mathrm{l}$ - for fungi and yeast. The seria dilutions were inoculated on nutrient media. The plates with mesophilic aerobic and anaerobic bacteria were incubated on meat peptone agar medium (Imuna, Slovak Republic) for 48-72 hours at $25{ }^{\circ} \mathrm{C}$ in appropriate conditions; Lactobacillus were incubated on MRS Agar Modified (HiMedia, India) for 48-72 hours at $37^{\circ} \mathrm{C}$; Enterococcus - on Slanetz-Bartley medium (HiMedia, India) for 48-72 hours at $37{ }^{\circ} \mathrm{C}$; coliform bacteria - on violet red bile with lactose agar (Pronadisa, Spain) for 24-48 hours at $37{ }^{\circ} \mathrm{C}$ and fungi on Sabouraud medium (Biomark Laboratories, India) for $5-7$ days at $25^{\circ} \mathrm{C}$. The data are reported as $\log$ $\mathrm{cfu} / \mathrm{g}$. The analysis was performed after collecting of pollen and repeated after storage of pollen samples after 4 weeks in a cooler at $+4^{\circ} \mathrm{C}$.

\section{Statistical analysis}

Results were evaluated by standard techniques using MS Excel and Statistica 10 Wilcoxon test was used for comparison the data for dependent samples.

\section{RESULTS AND DISCUSSION}

Microbial content of Betula and Pinus pollen samples is presented in Figure 2.

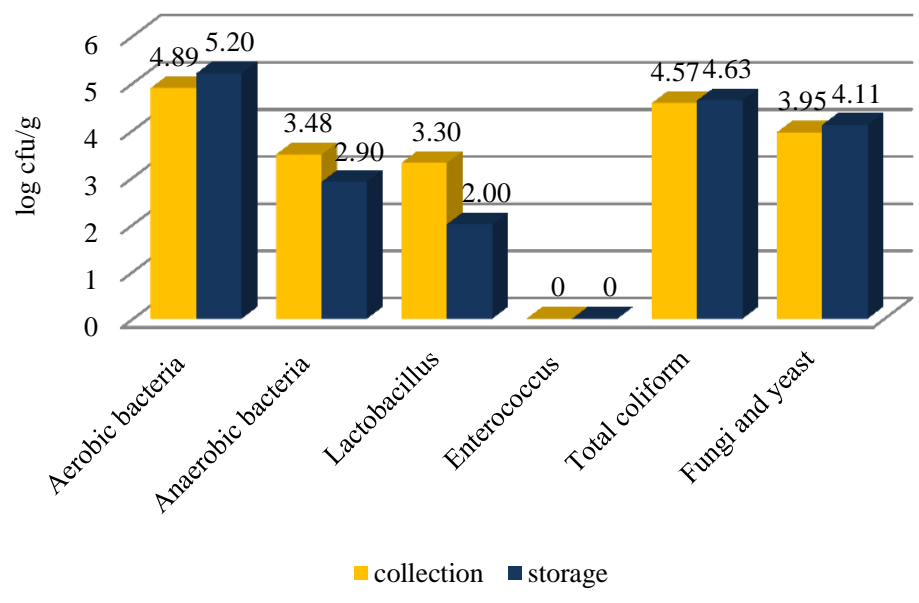

Pollen of Betula verrucosa Ehrh. (BV1)

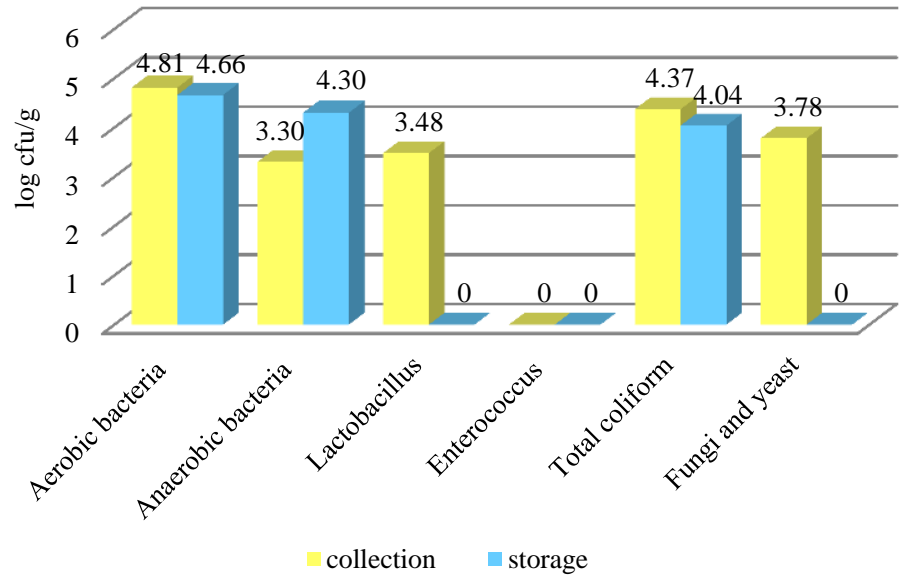

Pollen of Betula verrucosa Ehrh. 'Youngii' (BV2) 


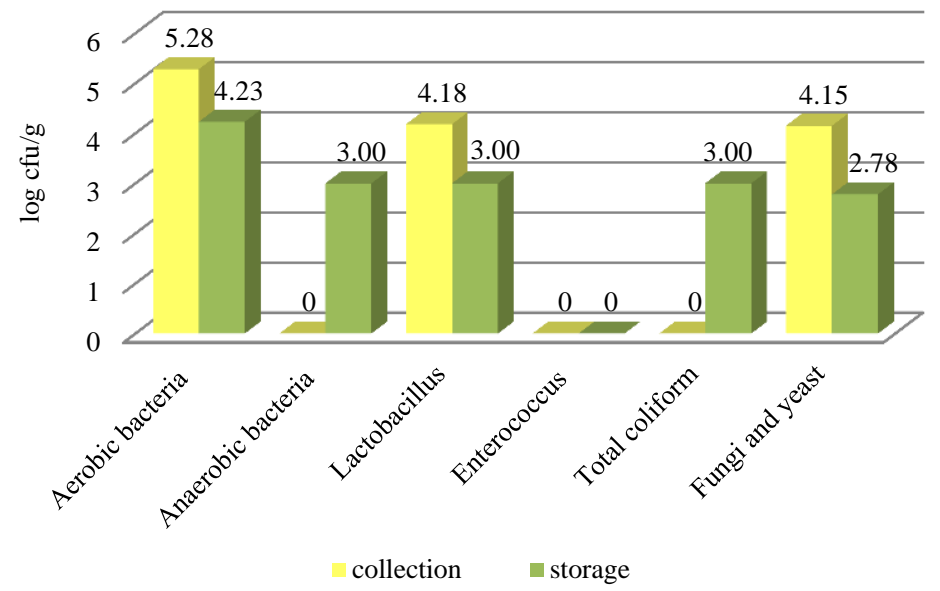

Pollen of Pinus sylvestris L. (1PS)

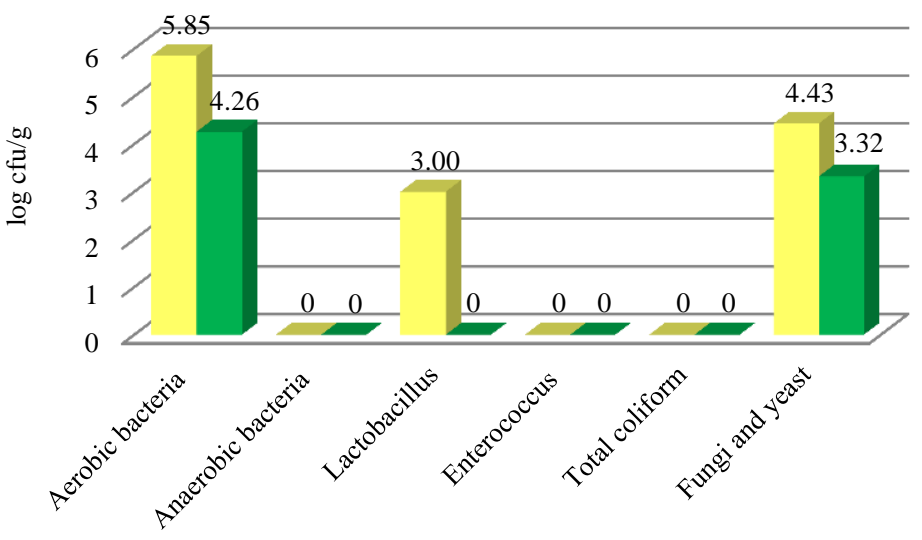

collection $\quad$ storage

Pollen of Pinus sylvestris L. (2PS)

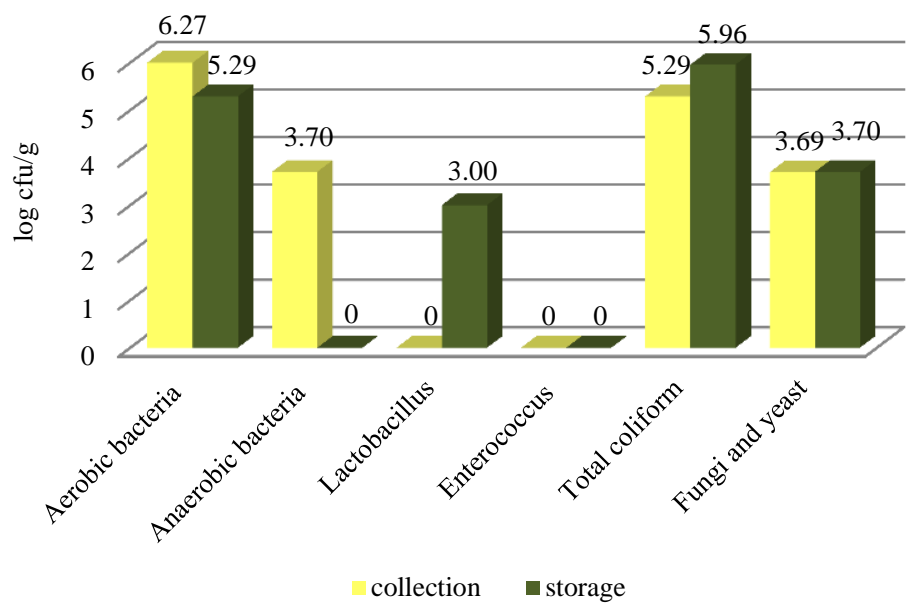

Pollen of Pinus nigra Arnold (3PN)

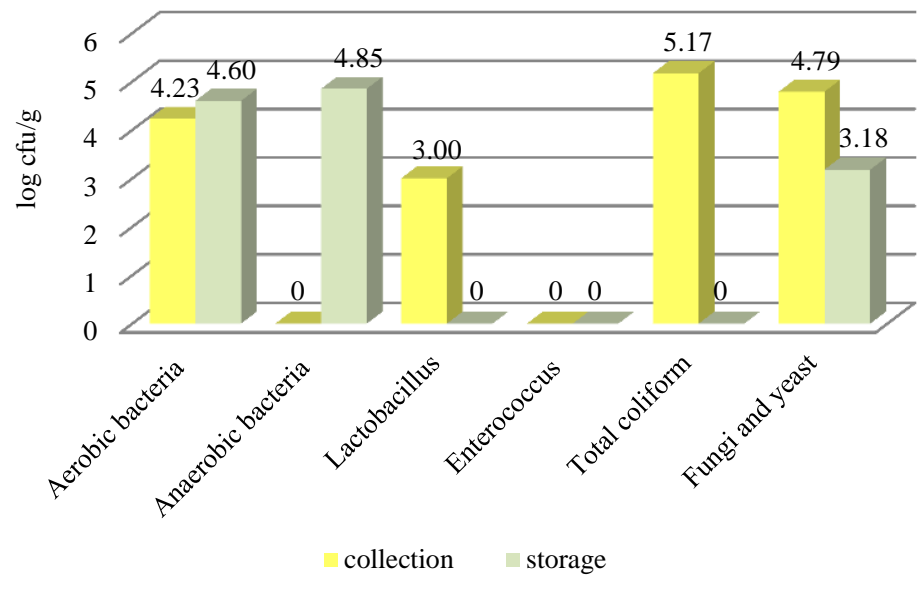

Pollen of Pinus mugo Turra (4PM)

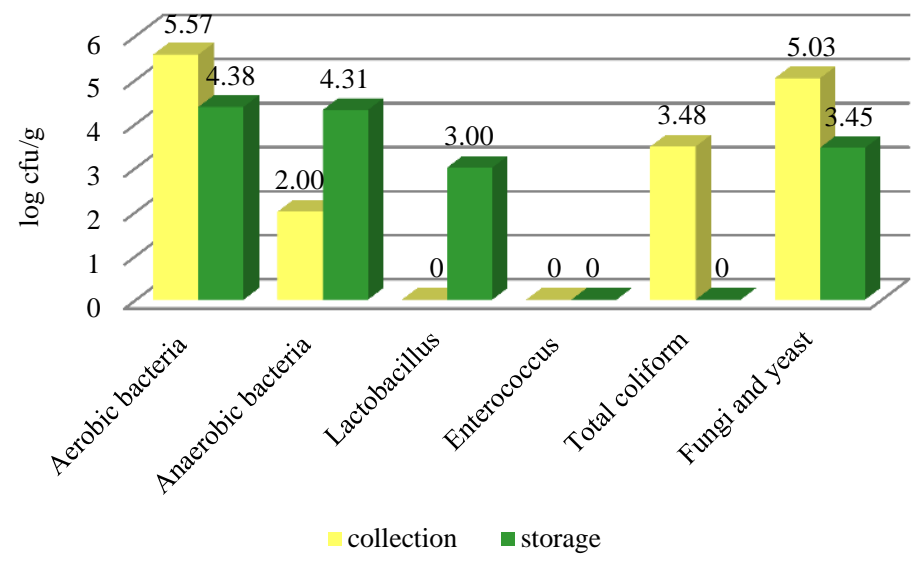

Pollen of Pinus armandii Franch. (5PA)

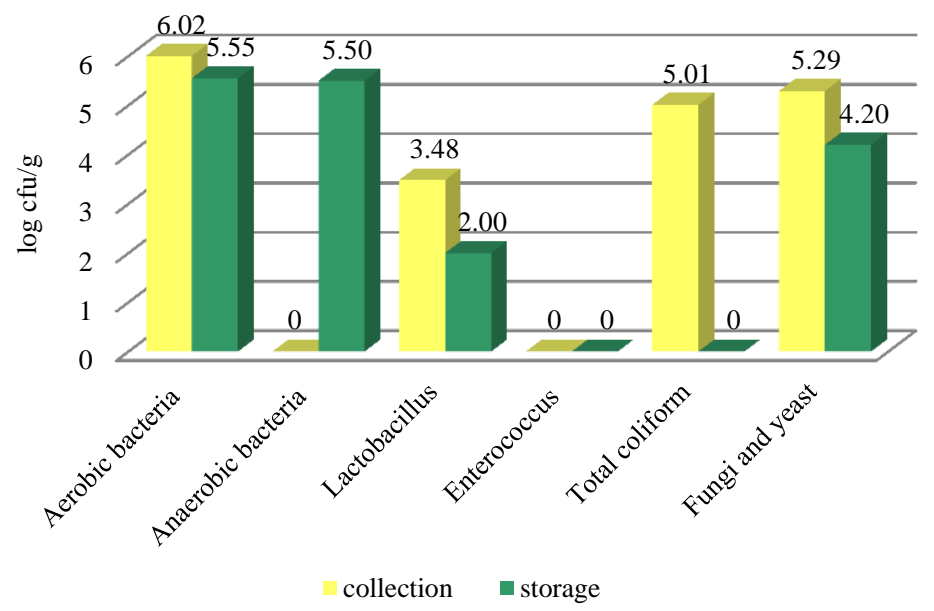

Pollen of Pinus wallichiana A.B. Jacks (6PW)

Figure 2 Microbial content of Betula and Pinus pollen samples after collection and storage

As can be seen from Figure 2 there is no general tendency in changing the microbiological contamination by different groups of microorganisms of anemophilous pollen of Betula and Pinus. Also, there is no a recurring order of decreasing or increasing the colonies of microorganisms according to the stages: collection or storage for the studied species of Betula and Pinus. In whole, the total number of mesophilic aerobic bacteria of Betula pollen after collecting is $4.85 \log \mathrm{cfu} / \mathrm{g}$, after storage - $4.93 \mathrm{log} \mathrm{cfu} / \mathrm{g}$, Pinus pollen - 5.54-4.72 log cfu/g respectively. The amount of mesophilic anaerobic bacteria of Betula pollen after collecting is $3.39 \mathrm{log} \mathrm{cfu} / \mathrm{g}$, after storage $-3.60 \mathrm{log} \mathrm{cfu} / \mathrm{g}$, Pinus pollen - 0.95 $2.94 \mathrm{log} \mathrm{cfu} / \mathrm{g}$ respectively. That is Betula pollen contaminated by mesophilic bacteria more. The number of lactobacilli is charged on the Betula pollen after collection as $3.30 \mathrm{log} \mathrm{cfu} / \mathrm{g}$, after storage - $1.00 \mathrm{log} \mathrm{cfu} / \mathrm{g}$, on pollen of Pinus - 
$1.78-1.83 \log \mathrm{cfu} / \mathrm{g}$ respectively. On the content of the representatives of the Enterococcus genus pollen of all species is of excellent quality $(0.00 \mathrm{log} \mathrm{cfu} / \mathrm{g})$, both after collection and after storage for one month. Pollen quality is worse because of the content of coliform bacteria: value of Betula pollen after collection is $4.47 \mathrm{log} \mathrm{cfu} / \mathrm{g}$, after storage - $4.34 \mathrm{log} \mathrm{cfu} / \mathrm{g}$, pollen of Pinus - 3.16-1.49 log $\mathrm{cfu} / \mathrm{g}$ respectively. On the content of fungi and yeasts values are the next: for Betula pollen after collection is $3.87 \mathrm{log} \mathrm{cfu} / \mathrm{g}$, after storage $-2.06 \mathrm{log} \mathrm{cfu} / \mathrm{g}$, for Pinus pollen $-4.56-3.44 \log \mathrm{cfu} / \mathrm{g}$ respectively.

It was found that Betula pollen after collection has a good quality under comparing received values of pollen contamination with the microbial recommendations of Campos et al. (2008): the amount of aerobic bacteria does not exceed $<100000 / \mathrm{g}(65000-77000 \mathrm{cfu} / \mathrm{g})$, fungi and yeast $-<50000 / \mathrm{g}(6000$ $9000 \mathrm{cfu} / \mathrm{g}$ ); after storage quality of Betula verrucosa Ehrh. (BV1) pollen degraded by the content of aerobic bacteria $(46000-160000 \mathrm{cfu} / \mathrm{g})$. Pinus pollen is of poor quality after the pollen handling: the amount of aerobic bacteria exceeds the rate of 1.7-18.7 times, fungi and yeast - in three cases out of six (4PM, 5PA 6PW) in 1.2-3.9 times. After storage the microbiological quality of Pinus pollen is better: the content of aerobic bacteria exceeded the norm only in two cases out of six for 3PN (195000 cfu/g) and 6PW (358000 cfu/g). The number of colonies of yeasts and fungi is reduced and is not excessive.

When comparing the microbiological quality of anemophilous pollen, depending on the stage of the processing (collection and storage) for birch pollen found only a tendency to a predominance of Lactobacillus colonies in pollen after collection, compared with pollen after storage $(\mathrm{p}=0.068)$ (Figure 3$)$. For Pinus pollen it was found significant difference in the presence of microscopic fungi and yeast $(\mathrm{T}=0$, $\mathrm{p}=0.0022$ ), indicating a preponderance of their colonies in pollen samples after collection in comparison with pollen after storage (Figure 4).

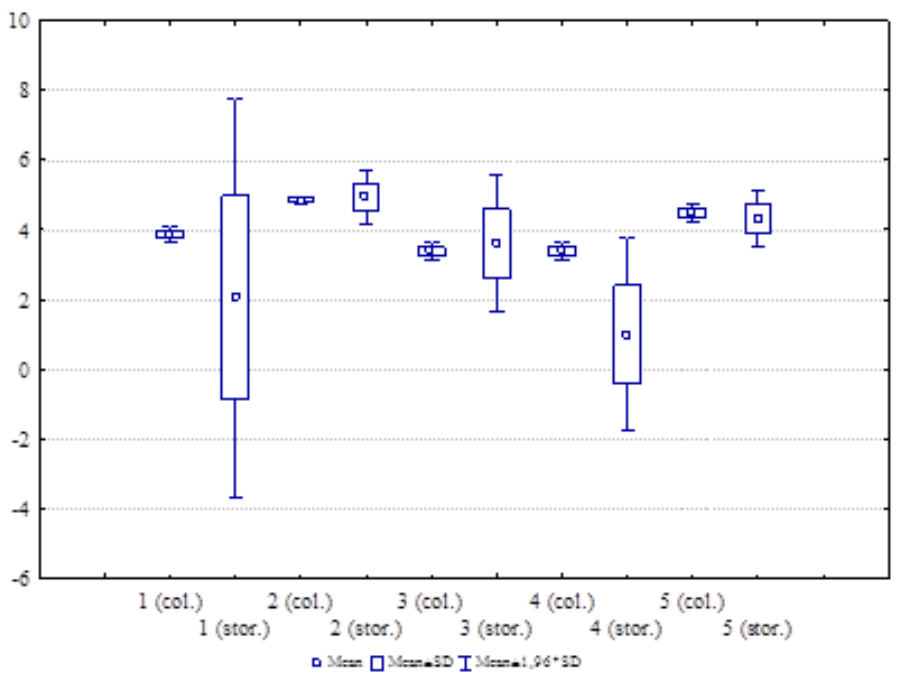

Figure 3 Box \& Whisker Plot for comparison of microbiological quality of Betula pollen after collection and storage: 1 - Fungi and yeast; 2 - Aerobic bacteria; 3 - Anaerobic bacteria; 4 -Lactobacillus; 5 - Total coliform

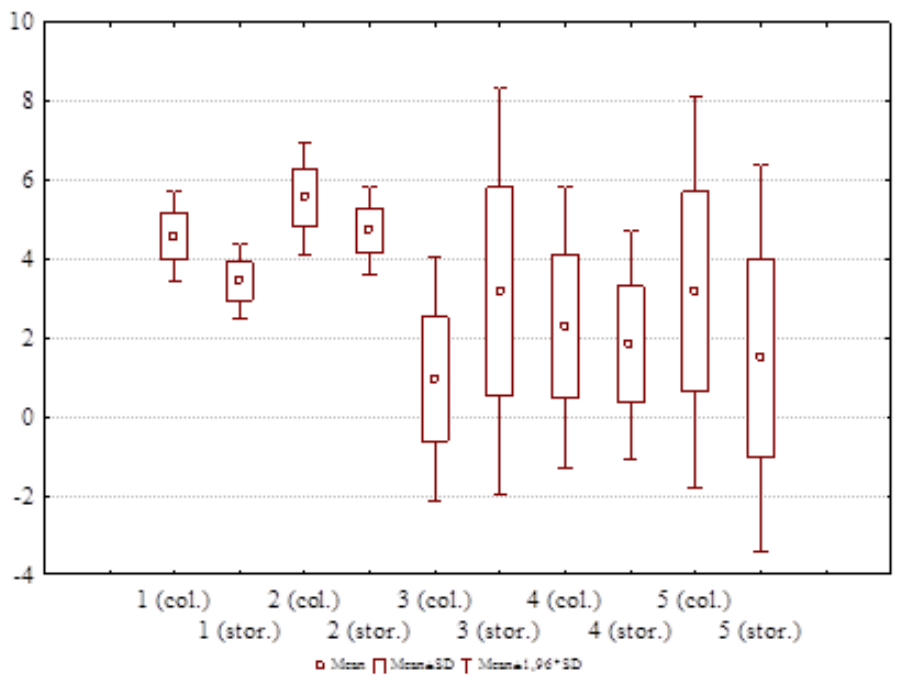

Figure 4 Box \& Whisker Plot for comparison of microbiological quality of Pinu pollen after collection and storage: 1 - Fungi and yeast; 2 - Aerobic bacteria; 3 Anaerobic bacteria; 4 - Lactobacillus; 5 - Total coliform

Thus, pollen of Betula is of good quality after collection. Only the content of lactobacilli significantly changes in the direction of their reduction after storage during one month. Pinus pollen is the worst microbiological quality after collection, than birch pollen, but after the storage there is a tendency for improving its quality by reducing the amount of microscopic fungi and yeasts colonies.

Differences in microbiological quality of anemophilous pollen of Betula and Pinus under identical conditions of collection and storage can be explained by differences in chemical composition. Přidal (2003) compared the chemical composition of the different species of pollen, including pine and birch. Thus, the amount of proteins in the pollen of Betula is $23.02 \%$, in Pinus pollen $-14.14 \%$, lipids -2.67 and $1.23 \%$ respectively, carbohydrates -16.69 and $30.92 \%$ respectively, minerals -2.97 and $2.24 \%$ (Nôžková et al., 2014).

The main enemy of pollen quality in storage is its water content. High humidity is an ideal culture medium for microorganisms like bacteria, fungi and yeast (Szczesna et al., 1999; Campos et al., 2008; Nôžková et al., 2014). Therefore it is recommended to collect it every day and immediately frozen or it must be dried and vacuum-packed quickly (Medina et al., 2004). After defrosting to process or use pollen as soon as possible. Also drying and lyophilization are discussed as methods of processing of fresh pollen (Brovarskij $\boldsymbol{e t}$ al., 2010; Nôžková et al., 2014). It was found after microbiological analysis of bee pollen of Helianthus annuus L., Brasica napus var. napus L., Papaver somniferum L. in three forms of preservation - drying, freeze-drying and freezing, the most effective against the growth and reproduction of microscopic fungi, coliforms and mesophilic aerobic bacteria is the method of freezing, against mesophilic anaerobic bacteria - the drying process. Also, for each species of pollen an individual approach is necessary, which is due to its chemical composition and physical properties (Nôžková et al., 2014).

Cooling, as in our case, reduces the rate of biochemical reactions of microorganisms. Under cooling decomposition retards and thermophilic species for which the optimum temperature is above $37^{\circ} \mathrm{C}$ and mesophilic bacteria with a temperature optimum of $10-40{ }^{\circ} \mathrm{C}$ do not multiply. For example, Escherichia coli stops to multiply at $2^{\circ} \mathrm{C}$. The advantage of cooling that the food cannot be changed separate physical, but mainly chemical modifications. Therefore, sufficient cooling the product is unsuitable environment for the growth of microorganisms. Cooling can extend the shelf life of most foods only for a relatively short time. Přidal (2005) does not recommend to store pollen in a refrigerator at several degrees of heat as it as a result will grow mouldy. At preservation of products, cold storage well be used only to extend the shelf life of raw materials to the actual production process (Nôžková et al., 2014).

Thus, right collected anemophilous pollen from healthy plants may be used in pharmaceutical or cosmetic industry immediately after collection or after storage. To ensure the proper storage of pollen it is sufficiently placing it on the day in a freezer after collection and purification and then stored in a refrigerator in a dry and dark place, if pollen planning to use in a short time. In the case of long-term storage is better to freeze pollen.

\section{CONCLUSIONS}

As a result of analysis, it was found that anemophilous pollen of Betula and Pinus differ in existing microbiota at the stage of collecting. After collecting birch pollen has better microbiological quality according to existing microbial aspects. There is a change in the composition of their microbiological associations at the stage of storage for one month at $+4^{\circ} \mathrm{C}$. There is a tendency to improve the microbiological quality of pine pollen by reducing the amount of microscopic fungi and yeast. Birch pollen does not lose its quality during provided storage conditions. The considered storage conditions of Betula and Pinus pollen can be recommended for widespread use or at least at the national level.

Acknowledgments: Co-author T. Shevtsova is grateful to National Scholarship Programme of the Slovak Republic for providing a scholarship for the research internship, during which she received the results and knowledge presented in this paper. This work has been supported by the Excellence Center for Agrobiodiversity Conservation and Benefit (ECACB) project implemented under the Operational Programme Research and Development financed by European Fund for Regional Development, ITMS 26220120015.

\section{REFERENCES}

Bogdanov, S. (2004). Quality and Standards of Pollen and Beeswax. Apiacta, 38 334-341.

Brindza, J., Gróf, J., Bacigálová, K., Ferianc, P. \& Tóth, D. (2010). Pollen microbial colonization and food safety. Acta Chimica Slovaca, 3(1), 95-102.

Brovarskij, V. \& Brindza, J. (2010). Včelí obnôžkový pel’. Kyjev-Nitra: FOP I. S. Maidachenko.

Campos, M. G. R., Bogdanov, S., Bicudo de Almeida-Muradian, L., Szczesna, T., Mancebo, Y., Frigerio, Ch. \& Ferreira, F. (2008). Pollen composition and standardisation of analytical methods. Journal of Apicultural Research and Bee World, 47(2), 156-163. DOI: http://dx.doi.org/10.3896/ibra.1.47.2.12

D'amato, G., Cecchi, L., Bonini, S., Nunes, C., Annesi-Maesano, I., Behrendt, H., Liccardi, G., Popov, T. \& Van Cauwenberge, P. (2007). Allergenic pollen and 
pollen allergy in Europe. Allergy, 62, 976-990. DOI: http://dx.doi.org/10.1111/j.1398-9995.2007.01393.x

Feás, X., Pilar Vázquez-Tato, M., Estevinho, L., Seijas, J.A. \& Iglesias A (2012). Organic Bee Pollen: Botanical Origin, Nutritional Value, Bioactive Compounds, Antioxidant Activity and Microbiological Quality. Molecules, 17, 8359-8377. DOI: http://dx.doi.org/10.3390/molecules17078359

Gastaminza, G., Lombardero, M., Bernaola, G., Antepara, I., Muňoz, D., Gamboa, P. M., Audicana, M. T., Marcos, C. \& Ansotegui, I. J. (2009). Allergenicity and cross-reactivity of pine pollen. Clinical \& Experimental Allergy, $39, \quad 1438-1446 . \quad$ DOI: $\quad$ http://dx.doi.org/10.1111/j.13652222.2009.03308.x

Hani, B., Dalila, B., Saliha, D., Daoud, H., Mouloud, G. \& Seddik, K. (2012).

Microbiological sanitary aspects of pollen. Advances in Environmental Biology, 6(4), 1415-1420.

Kačániová, M., Petrová, J., Hleba, L., Shevtsova, T., Kluz, M., Rožek, P. \& Vukovič, N. (2014). Microscopic filamentous fungi occurrence in plant pollen from nontraditional plant species. Journal of Microbiology, Biotechnology and Food Sciences, 3(6), 522-524.

Madmony, A., Chernin, L., Pleban, S., Peleg, E. \& Riov, J. (2005). Enterobacter cloacae, an obligatory endophyte of pollen grains of Mediterranean pines. Folia Microbiol., 50(3), 209-216. DOI: http://dx.doi.org/10.1007/bf02931568

Masclaux, H., Bec, A., Kagami, M., Perga, M.-E., Sime-Ngando, T., Desvilettes,

C. \& Bourdier G. (2011). Food quality of anemophilous plant pollen for zooplankton. Limnol. Oceanogr., 56(3), 939-946. DOI http://dx.doi.org/10.4319/lo.2011.56.3.0939

Medina, Á., González, G., Sáez, J. M., Mateo, R. \& Jiménez, M. (2004). Bee Pollen, a Substrate that Stimulates Ochratoxin A production by Aspergillus ochraceus Wilh. System. Appl. Microbiol., 27, 261-267. DOI: http://dx.doi.org/10.1078/072320204322881880.

Mittag, D., Varese, N., Scholzen, A., Mansell, A., Barker, G., Rice, G., Rolland, J. M. \& O'hehir, R. E. (2013). TLR ligands of ryegrass pollen microbial contaminants enhance Th1 and Th2 responses and decrease induction of Foxp3(hi) regulatory $\mathrm{T}$ cells. Eur. J. Immunol., 43(3), 723-33. DOI: http://dx.doi.org/10.1002/eji.201242747

Nôžková, J., Kačániová, M. \& Fatrcová-Šramková, K. (2014). Hodnotenie kvality obnôžkového pel'u. Nitra: Vydavatel'stvo SPU v Nitre.

Shevtsova, T., Hleba, L., Kačániová, M., Brindza, J. \& Garkava, K. (2013)

Antibiotic resistance of Escherichia coli isolated from Ukrainian Betula verrucosa Ehrh. pollen after microbiological analysis. Journal of Microbiology, Biotechnology and Food Sciences, 3(1), 94-96.

Shevtsova, T., Kačániová, M., Garkava, K., Brindza, J. \& Petrova J. (2014) Contamination of Betula verrucosa Ehrh. pollen by microorganisms, mycotoxins and heavy metals. Journal of Microbiology, Biotechnology and Food Sciences, 3(6), 509-513.

Spiewak, R., Krysińska-Traczyk, E., Sitkowska, J. \& Dutkiewicz, J. (1996). Microflora of allergenic pollens - a preliminary study. Annals of Agricultural and Environmental Medicine, 3, 127-130.

Szczesna, T., Rybak-Chmielewska, H. \& Chmielewski, W. (1999). Effect of infestation of pollen loads with acarid mites on amino acid content and organoleptic characteristics of the product. Pszczelnicze Zeszyty Naukowe, 43, $235-245$. 